UDC 621.391

\title{
INTERNET: MODELS, TECHNOLOGIES, ACCESS SPEED, PROSPECTS
}

\author{
Oleksiy Nedashkivskiy, Anatoly Semenko \\ State University of Telecommunications, Kyiv, Ukraine \\ Aleksey Kozlov \\ Telecard-Pribor Ltd, Odessa, Ukraine \\ Natalia Bokla \\ National University of Lviv Polytechnic, Lviv, Ukraine
}

Background. Open multiservice network of telecommunications the Internet has become the most used source of such vital information as: scientific and technical, information, entertainment, and, especially, commercial. Today, it unites 3.36 billion users and provides high economic efficiency of human activity. However, there are many different technologies for accessing Internet services that compete with each other.

Objective. The aim of the paper is to create the Internet network model and a content access model, as the main value of the network from the point of view of the end user, for building an effective network infrastructure.

Methods. Analysis of all known publications on the construction and evaluation of Internet service quality parameters. Analysis of technologies for accessing the network and content. Synthesis of the model of formation and distribution of traffic between levels of the hierarchy of the Internet.

Results. Enlarged indicators of Internet services provision were received. An enlarged scheme for building a global Internet network is proposed. Based on the generalized "end-to-end" scheme of user access to services and network resources, an estimate of the amount of sufficient access speed was obtained. The concepts of hierarchy level and gravitational coefficient are defined for which mathematical relations are derived.

Conclusions. The main task of the providers of any level is to close the traffic as close as possible to the client, i.e. to reduce the gravity coefficient. The task of theoreticians and engineers is to determine theoretically the optimal number of levels (there were only three of them in the model in question) of closure or aggregation of traffic.

Keywords: Internet; access network; quality indicator; availability indicator; access speed.

\section{Introduction}

In 1967 a plan arose for building the ARPANET network, the main task of which was to provide realtime interaction of computers of various scientific centers and research groups working for the US Department of Defense.

The development of the network was based on the ideas of the network concept of "The Galactic Network" of Joseph Licklider (1962) as a global network of interconnected computers, through which everyone can quickly access data and programs located on any Computer, as well as using the Paul Baran (1962) method of packet switching for the transmission of information in telecommunication networks [1].

Since October 1972, from technology for military, the network has increasingly turned into a telecommunications network for scientists when Robert Kahn expressed the idea of an open network architecture for which individual networks can be designed and developed independently, with their unique interfaces provided to users and/or other network service providers with special requirements. And since the Network Control Protocol (NCP) established in 1971 - 1972 on ARPANET nodes did not meet the requirements of open systems, Kahn, together with Vinton Cerf, developed a new protocol, which was later called Transmission Control Protocol/Internet Protocol (TCP/IP). This protocol has spread to many networks and has allowed the integration of various networks, which today are called the Internet.

Finally, in 1989, Tim Berners-Lee proposed a global hypertext project, now known as the World Wide Web. To implement the project, Tim Berners-Lee (along with his assistants) invented URI, the HTTP protocol, and the HTML language, technology, without which it is impossible to imagine the modern Internet.

\section{Global Indicators of Internet Service Providing}

In 1995, the real Internet boom began, turning the 
Network into the most dynamic and accessible medium of mass communication, which today already has 3.36 billion users worldwide.

The Internet from the scientific point of view is a classical open telecommunications system that by definition supports any equipment, any provider, any user and data of any nature that are supported by generally accepted international standards.

Services based on the Internet are services that are provided to the end user (client) application. The quality of Internet services can be estimated in the first approximation by enlarged global criteria.

The availability indicator is formed based on the potential (coverage area) and real (number of users) penetration. The specific indicator of availability by coverage area, expressed as a percentage, will be:

$$
Z_{1}=\frac{S_{i}}{S_{\Sigma}} \cdot 100 \%,
$$

where: $S_{i}$ - the area of the territory of the $i$-th country, within which there is a technical opportunity to connect to the Internet; $S_{\Sigma}$ - total area of the territory of the $i$-th country.

The specific indicator of the population's accessibility of the coverage area, expressed as a percentage, will be:

$$
Z_{2}=\frac{P_{i}}{P_{\Sigma}} \cdot 100 \%
$$

where: $P_{i}$ - the population of the $i$-th country, within which there is a technical opportunity to connect to the Internet; $P_{\Sigma}$ - total population of the $i$-th country.

For the specific penetration rate of the Internet, we have:

$$
Y=\frac{N_{i}}{P_{\Sigma}} \cdot 100 \%
$$

where: $N_{i}$ - number of subscribers or users of the Internet of the $i$-th country.

As of early 2017, according to the State Statistics Service of Ukraine [2], the revenue from providing access to the Internet and mobile communications amounted to almost $70 \%$ of all revenues from the provision of mail and communication services. The most interesting is the dynamics of growth in the share of revenues from Internet access services in the amount of $1-2 \%$ per year, with a decrease in the share of revenues from mobile communications

According to Internet Live Stats [3] for 2016,
Ukraine is at 34 (32 in 2014) place by the number of users, 101 in terms of penetration and 171 in terms of growth. The annual increase was only $0.45 \%(9 \%$ in 2014 [4]), while the world average was $5.48 \%$ (6.6\% in 2014), indicating that the Internet in Ukraine has stopped developing at a faster pace. The maximum growth is observed in developing countries (Burundi, Eritrea $5.1 \%, 4.8 \%$ (17\% in 2014)), and the minimum in Andorra and Latvia, where the decline is $1.60 \%$ and $0.50 \%$ respectively (Sweden, Iceland by $1 \%$ in 2014). Growth in the United States of America, the home of the Internet, was $1.1 \%$ (7\% in 2014).

\section{Comparative Evaluation of Access Speed in the Internet}

The minimum, average and peak values of the Internet access speed are formed on the basis of the potentially achievable (the theoretical peculiarities of the specific technology of access and data transmission) and the achievable values (practical implementation in specific environmental conditions) of the results achieved.

One of the known methods for assessing the quality of the Internet is the allocation of broadband fixed speed access based on data of contractual rates of existing subscribers published by the International Telecommunication Union (ITU) in the annual reports of the Development of Information and Communication Technologies (ICT Development Index IDI) [5].

It is interesting to compare the specific speed of international Internet channels per one Internet subscriber for the top ten countries and Ukraine. Obviously, Ukraine occupying 76th place has the value of the specific bandwidth of international Internet channels per subscriber by only $2.23 \%$ less than the similar indicator of the leader of the world ranking of South Korea.

Another known method for assessing the quality rating of the Internet used by Akamai Technologies is the average speed of Internet connection [6]. The distribution of the average and average peak connection speed on the Internet for the top ten countries and Ukraine in the third quarter of 2016 is presented in Table 1.

In the "State of the Internet" report for the fourth quarter of 2016 [7] states that the average speed of the Internet connection in the world is $7 \mathrm{Mbit} / \mathrm{s}$, which is $14 \%$ more than the previous quarter and $26 \%$ more than a year ago.

The average and average peak speeds in Ukraine are $12.8 \mathrm{Mbit} / \mathrm{s}$ and $55.7 \mathrm{Mbit} / \mathrm{s}$, respectively, which is 2.05-2.06 times less than in South Korea. 


\section{The Scheme of the Global Internet Network}

In the diagram (Fig. 1), four areas of the Internet are distinguished, significant from the point of view of the impact on the quality of the services provided.

In the content zone there are "sources" of the end services (services): WEB, E-mail, FTP, VoIP, IP-TV, OTT, E-commerce, DB and "sources" of infrastructure services: DNS, NTP, etc.

The backbone of the IP transport consists of a set of interconnected high-speed optical and satellite channels of various Internet providers, which consist of internal and boundary routers.

Table 1. Average and average peak speed of Internet connection in the ten leading countries and Ukraine

\begin{tabular}{|l|l|l|}
\hline \multicolumn{1}{|c|}{ Country } & \multicolumn{1}{|c|}{$\begin{array}{c}\text { Average } \\
\text { speed, } \\
\text { Mbit/s }\end{array}$} & $\begin{array}{c}\text { Average } \\
\text { peak } \\
\text { speed, } \\
\text { Mbit/s }\end{array}$ \\
\hline South. Korea & 26468 & 114194 \\
\hline Iceland & 16760 & 79045 \\
\hline Denmark & 15603 & 59179 \\
\hline Switzerland & 17514 & 75153 \\
\hline United Kingdom & 14627 & 62882 \\
\hline $\begin{array}{l}\text { Hong Kong, } \\
\text { China }\end{array}$ & 19042 & 116150 \\
\hline Sweden & 18140 & 78962 \\
\hline Netherlands & 16111 & 71348 \\
\hline Norway & 18550 & 65379 \\
\hline Japan & 17195 & 88141 \\
\hline Ukraine & 12846 & 55711 \\
\hline
\end{tabular}

The access zone consists of a set of hardware that provides unified connection of consumers to the backbone IP transport zone. Due to the need to connect different devices and consumer groups, in different geographic conditions, with different types of mobility and the existing telecommunications infrastructure, it is in this zone wide range of signal transmission technologies is observed. Table 2 shows the main characteristics of access network technologies.

The zone of consumers of content, as a rule, is represented by Ethernet and Wi-Fi technology.

\section{Access Technologies of Internet Services}

Consider the key features of the most common access network technologies (Table 2).

The xDSL technology family allows you to organize both symmetric and asymmetric access channels. A key feature of $\mathrm{xDSL}$ is the use of existing telephone cables. Further increase of speed is possible only with a simultaneous decrease of the length of subscriber lines.

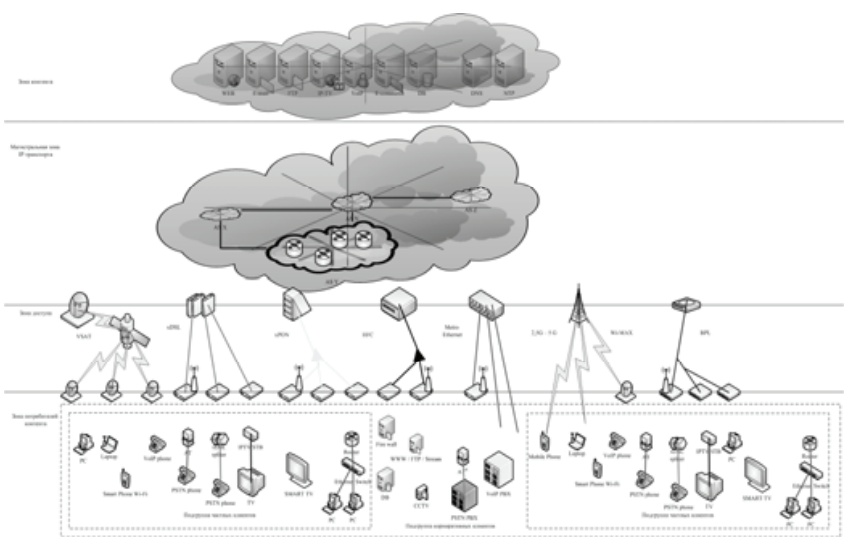

Fig. 1. The scheme of the global Internet network

Table 2. Key characteristics of main modern technologies of access networks

\begin{tabular}{|c|c|c|c|c|}
\hline \multirow[b]{2}{*}{$\begin{array}{l}\text { Name of the } \\
\text { technology } \\
\text { (standard) }\end{array}$} & \multicolumn{2}{|c|}{ Speed } & \multirow[b]{2}{*}{$\begin{array}{l}\text { Multi- } \\
\text { plier }\end{array}$} & \multirow[b]{2}{*}{$\begin{array}{c}\text { Distance, } \\
\text { km }\end{array}$} \\
\hline & $\begin{array}{l}\text { Down- } \\
\text { stream, } \\
\text { Mbit/s }\end{array}$ & $\begin{array}{c}\text { Up- } \\
\text { stream, } \\
\text { Mbit/s }\end{array}$ & & \\
\hline $\begin{array}{l}\text { ADSL2+M } \\
\text { (ITU G.992.5 } \\
\text { Annex M) }\end{array}$ & 24 & 3,3 & $1 / 1$ & $<3,5$ \\
\hline $\begin{array}{l}\text { VDSL (ITU-T } \\
\text { G.993.1) }\end{array}$ & 52 & 16 & $1 / 1$ & $<1,5$ \\
\hline $\begin{array}{l}\text { VDSL2 (ITU-T } \\
\text { G.993.2) }\end{array}$ & \multicolumn{2}{|c|}{ total 200} & $1 / 1$ & $<0,5$ \\
\hline $\begin{array}{ll}\begin{array}{l}\text { Fast Ethernet } \\
\text { (Cat.5) }\end{array} & \\
\end{array}$ & 100 & 100 & $1 / 1$ & $<0,1$ \\
\hline $\begin{array}{l}\text { Gigabit Ethernet } \\
\text { (Cat.5) }\end{array}$ & 1000 & 1000 & $1 / 1$ & $<0,1$ \\
\hline $\begin{array}{l}\text { Gigabit Ethernet } \\
\text { (FO) }\end{array}$ & 1000 & 1000 & $1 / 1$ & $<120$ \\
\hline BPL & \multicolumn{2}{|c|}{ total 500} & $1 / \mathrm{N}$ & $<1,5$ \\
\hline DOCSIS 2.0 & 42,88 & 30,72 & $1 / \mathrm{N}$ & $<150$ \\
\hline $\begin{array}{l}\text { EURODOCSIS } \\
2.0\end{array}$ & 55,62 & 30,72 & $1 / \mathrm{N}$ & $<150$ \\
\hline DOCSIS 3.0 & $\mathrm{~m} \cdot 42,88$ & $\mathrm{n} \cdot 30,72$ & $\begin{array}{l}\mathrm{m}(\mathrm{n}) / \\
\mathrm{N}\end{array}$ & $<150$ \\
\hline $\begin{array}{l}\text { EURODOCSIS } \\
3.0\end{array}$ & $\mathrm{~m} \cdot 55,62$ & $\mathrm{n} \cdot 30,72$ & $\begin{array}{l}\mathrm{m}(\mathrm{n}) / \\
\mathrm{N}\end{array}$ & $<150$ \\
\hline VSAT & 50 & 10 & $1 / \mathrm{N}$ & $<15000$ \\
\hline $\begin{array}{l}\text { GPON (ITU-T } \\
\text { G.984.x) }\end{array}$ & 2488 & 2488 & $\begin{array}{l}1 / \\
\max \\
128\end{array}$ & $<20$ \\
\hline $\begin{array}{l}\text { 10G-EPON } \\
\text { (IEEE 802.3av- } \\
\text { 2009) }\end{array}$ & 10000 & 10000 & $\begin{array}{l}1 / \\
\max \\
64\end{array}$ & $<20$ \\
\hline $\begin{array}{l}\text { WiMAX } \\
(802.16 \mathrm{~d})\end{array}$ & \multicolumn{2}{|c|}{$\begin{array}{l}\text { total } 75 \text { (for TDD) } \\
\text { or } 150 \text { (for FDD) }\end{array}$} & $1 / \mathrm{N}$ & $<25$ \\
\hline $\begin{array}{l}\text { Mobile WiMAX } \\
(802.16 \mathrm{e})\end{array}$ & \multicolumn{2}{|c|}{$\begin{array}{c}\text { total } 40 \text { (for TDD) } \\
\text { or } 80 \text { (for FDD) }\end{array}$} & $1 / \mathrm{N}$ & $<5$ \\
\hline $\begin{array}{ll}\text { WiMAX } & 2 \\
(802.16 \mathrm{~m}) & \\
\end{array}$ & \multicolumn{2}{|c|}{$\begin{array}{l}\text { total } 1000 \text { (for TDD) } \\
\text { or } 1000 \text { (for FDD) }\end{array}$} & $1 / \mathrm{N}$ & $<120$ \\
\hline 3G: UMTS & 14,4 & 5,76 & $1 / \mathrm{N}$ & $<20$ \\
\hline 4G: LTE & 300 & 75 & $1 / \mathrm{N}$ & $<10$ \\
\hline
\end{tabular}


A family of Ethernet technologies allows you to organize symmetric access channels using both twisted pair cables and optical cables. It should be specially noted that the Ethernet family technologies can be considered self-sufficient, since with their help it is possible to build not only access networks, but also local as well as municipal (large city-size) networks.

The technology families BPL, DOCSIS, VSAT, PON are conceptually very similar. They all allow you to create both symmetric and asymmetric access channels. A common key feature of these technologies is the common transmission medium shared by one or another multiple access technology: FDMA, TDMA, CDMA. In fact, in these networks, the total available transfer rate in the cluster is divided between all the active devices under the control of the "head modem". BPL technologies use existing 10/0.4 kV public electric power distribution wiring. DOCSIS technologies use existing cable television networks. VSAT technologies use the resources of existing and special communication satellites. A key feature of VSAT is the possibility of $100 \%$ coverage of the Earth's territory both on land and at sea. Technologies of the PON family require the construction of a tree-like optical network consisting of sections of optical fibers and passive optical splitters.

The WiMAX, 3G and 4G technology families allow creating both symmetric and asymmetric access channels. A common key feature of these technologies is the common radio transmission medium shared by one or another multiple access technology: FDMA, TDMA, CDMA, OFDM. A key feature of mobile access systems is the ability of the user to move without stopping the connection.

\section{Evaluation of Sufficient Access Speed}

Sources of Internet services (Internet Source) can be of any nature: static or dynamic WEB site; IPTV, OTT or Internet radio; Mail or FTP server; Server or VoIP gateway; game server or cloud computing system. The recipient of the Internet services is the terminal subscriber device (Customer Equipment), connected to the client's local network (Customer LAN) Fig. 2.

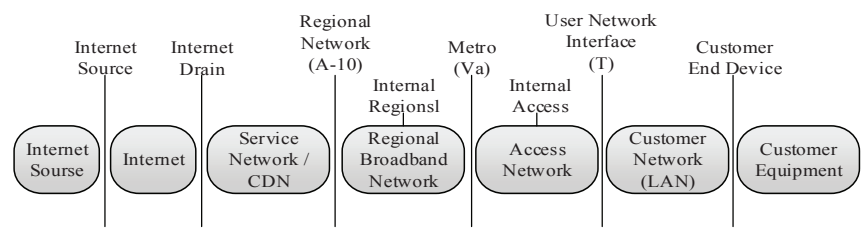

Fig. 2. General "end-to-end" scheme for user access to Internet services and resources

Obviously, at the "T" point, streams from all content sources that are consumed by the client local network
(Customer LAN) at a specific time are added.

There are two groups of content. The first group during the session requires almost constant throughput. That is, when determining the minimum network connection speed, it is necessary to add all threads that must simultaneously be received/transmitted to/from the client's network. The second group during the session can adjust the flow rate to the available free bandwidth. Accounting for the minimum necessary speed here depends solely on the economic and behavioral characteristics of customers and users.

According to statistical data, the average household volume in Ukraine is 2.8 people. Then the maximum traffic will be 2.8 of maximum flows. This means that for the average household, the lower limit will be 2.8 $4.5=7 \mathrm{Mbit} / \mathrm{s}$ when watching standard SDTV (MPEG-4) television, and the top will be when watching high-definition television HDTV (MPEG-4) and will be $2.8 \cdot 10=28 \mathrm{Mbit} / \mathrm{s}$.

It can be argued that the average person either watches TV, or browses WWW pages. In the first case, the download time of a WWW page with an average size of 18.4 Mbit will be $18.4 / 7=2.63$ seconds, and in the second $18.4 / 28=0.65$ seconds, which may be acceptable for some users and unacceptable for others. Ultimately, each subscriber makes a decision individually.

For mobile clients, the previous reasoning is true if we assume that at the maximum load hour, the maximum traffic will not be 2.8 of maximum streams, but 1 . Then the lower limit will be $1 \cdot 2.5=2.5 \mathrm{Mbit} / \mathrm{s}$ when watching standard SDTV (MPEG-4) video, and the upper one will be $1 \cdot 10=10 \mathrm{Mbit} / \mathrm{s}$ when watching high-quality video of HDTV (MPEG-4). In the first case, the download time of the WWW page with an average size of 18.4 Mbit will be $18.4 / 2.5=7.36 \mathrm{~s}$, and in the second $18.4 / 10=1.84 \mathrm{~s}$.

From the foregoing it can be seen that to date, acceptable access technology can be provided by access network technologies capable of providing access speed at the "T" point of at least 28-30 Mbit/s.

In general, the requirements for the minimum access speed of the average household at the "T" point can be defined as follows:

$$
C_{0}=\sum_{i=1}^{m} C_{i},
$$

where: $C_{i}$ - required minimum speed of the $i$-th stream; $m$ - maximum number of stream. 
The next place that affects the quality of Internet services, according to Fig. 2 is the actual Access Network. We estimate the maximum number of users in units of the average household for different access technologies.

In access technologies (BPL, DOCSIS, VSAT, PON, WiMAX UMTS, LTE) that use a shared media environment, the estimate of the maximum number of households at the access network level can be calculated using:

$$
N=\frac{C_{1}}{C_{0}}
$$

where: $N$ - maximum number of households that can be simultaneously served; $C_{1}-$ access network bandwidth.

It is known that part of the subscriber traffic can start and end within the access network itself, that is, not to enter the transport network of the provider and, especially, beyond the national segment of the Internet: there is no sense in transferring traffic between two customers living in neighboring apartments in Kyiv over Paris. Each operator is required to create all conditions for the maximum possible closure of traffic at levels as close as possible to the subscriber.

To do this, we introduce the gravity coefficient $G_{S}$ inside the level $S$ of the Internet hierarchy, as the ratio of the total required speed in the direction of the higher level to the total required rate of the lower level:

$$
\left\{\begin{array}{c}
G_{S}=\frac{C_{S+1}}{C_{S}}, \\
S \geq 1
\end{array}\right.
$$

where: $G_{S}$ - gravity coefficient within the hierarchy level $S$; $C_{S+1}$ - total required speed in the direction of the higher level hierarchy; $C_{S}$ - total required speed of the current hierarchy level; $S$ - hierarchy level.

Then $G_{1}$ will be the gravity coefficient inside the access level; $G_{2}$ - the gravity coefficient inside the core level (transport network) of the Internet provider; $G_{3}$ the gravity coefficient within the level of the national segment of the Internet.

Now, knowing the maximum required bandwidth of all $k$ access networks $C_{1_{j}}$ and the corresponding gravity coefficients within the access layer $G_{1 j}$, we can estimate the bandwidth requirements in the direction of the provider's transport network:

$$
C_{2}=\sum_{j=1}^{k} C_{1_{i}} \cdot G_{1_{i}}
$$

where: $C_{2}$ - required throughput in the direction of the provider's transport network; $k$ - number of access networks.

Reasoning similarly, we can estimate the minimum requirements for the speed of channels in the direction of the national Internet segment $C_{3}$ :

$$
C_{3}=C_{2} \cdot G_{2},
$$

where: $C_{3}$ - necessary bandwidth in the direction of the national Internet segment; $C_{2}$ - throughput of the provider's transport network; $G_{2}$ - gravity coefficient within the provider's transport network.

Finally, it is possible to estimate the minimum requirements for international Internet channels $C_{4}$ :

$$
C_{4}=C_{3} \cdot G_{3},
$$

where: $C_{4}$ - necessary bandwidth in the direction of the international Internet segment; $C_{3}$ - bandwidth of the national Internet segment; $G_{3}$ - gravity coefficient within the national segment of the Internet.

In total for the entire national segment of the Internet, the minimum requirements for international channels are determined by the summation over all access networks of all transport networks of all providers weighted by the corresponding gravity coefficients:

$$
C_{4_{\Sigma}}=\sum_{f=1}^{t}\left[\sum_{j=1}^{k}\left[\sum_{i=1}^{n}\left[N_{i} \cdot C_{0 i} \cdot G_{1 i}\right] \cdot G_{2_{j}}\right] \cdot G_{3_{f}}\right],
$$

where: $t$ - number of Internet providers; $k$ - number of transport network segments; $n$ - number of access network segments; $N_{i}$ - maximum number of subscribers per $i$-th segment of the access network; $C_{0_{i}}$ - minimum required access speed of the average household at the "T" point of the $i$-th segment of the access network; $G_{1 i}, G_{2 j}, G_{3 f}$ - gravity coefficients within the access level, the core and the national Internet segment, respectively.

Obviously, the values of the gravity coefficients can not exceed of 1 , that is, the access channels to the international section of the Internet can not exceed the sum of the access speed of the end customers. The main 
task of the providers of any level is to close the traffic as close as possible to the client, i.e. decrease the gravity coefficients. The task of theoreticians and engineers is to determine theoretically the optimal number of levels (there were only three), closure or aggregation of traffic.

\section{Conclusions}

1. The open multiservice telecommunication network has become the most used source of such vital information as: scientific and technical; informational, entertainment and, especially, commercial. Today, it unites 3.36 billion users and provides high economic efficiency of human activity.

2. The structure of the Internet can be represented in the form of four planes or functional zones: a content area; the backbone of the IP transport; access zone; user zone.

3. The Internet must provide services to users in accordance with QoS parameters and an agreed SLA quality level.

4. The user access speed to the Internet "from end to end" is practically determined by the maximum speed of access to the network of its Internet provider.

5. The most promising technologies for access networks are Metro Ethernet, VDSL, DOCSIS, 4G and $5 \mathrm{G}$, and VSAT. The main technologies of transport networks are IP, SDH, VSAT. The main technologies for providing QoS parameters are IP DiffServ, RSVP, MPLS, RSVP-TE.

6. To date, the growth rate of the share of income from Internet access is up to $2 \%$ and outpacing the growth rate of the share of revenues from mobile communications. According to ITU's rating on the IT development index, Ukraine ranks is 76th, while the specific bandwidth of international Internet channels per subscriber is $45.7[\mathrm{kbit} / \mathrm{s}] /$ [subscriber], which is only $2.23 \%$ less than the world leader's Rating of South Korea. At the same time, according to the average and average peak Internet connection speed, Ukraine lags behind South Korea in 2.05-2.06 times. The main bottleneck in Ukraine is the quality of national access networks. Therefore, the main task of Ukraine is the modernization of existing access networks with the transition to FTTB, FTTC, 4G technologies.

7. With the growth of number of Internet users, and even more with its qualitative transition from the "People's Network" to the "Network of Things", the tendency of "approaching" content sources and data processing systems from the upper levels is closer to the access zone, that is, consumers content. At the same time, the content zone itself "dissolves" in the backbone of the IP transport; Access zone and even the zone of consumers of content, since some of the Internet traffic of things can and should be closed within the local network of the subscriber.

\section{References}

[1] Moore M., Telecommunications. A Beginner's Guide. - St. Petersburg: BHV-Peterburg, 2003. 624 p. [in Russian]

[2] Revenues from services provided by post and communication 2016 (Online, in Ukrainian): http://www.ukrstat.gov.ua.

[3] Internet Users by Country (2016) (Online): http://www.internetlivestats.com/internet-users-bycountry.

[4] Estimation of quality of Internet services in Ukraine / O. Nedashkivskiy // Modern Problems of Radio Engineering, Telecommunications and Computer Science, Slavske in Lviv region, 23 February, 2016 - 26 February, 2016, p.31.

[5] Measuring the Information Society Report 2016, International Telecommunication Union (Online): http:/www.itu.int/en/ITU-

D/Statistics/Documents/publications/misr2016/MIS R2016-w4.pdf.

[6] State of the Internet Report Akamai.htm (Online): https://www.akamai.com/uk/en/our-thinking/stateof-the-internet-report.

[7] Akamai's [state of the internet] Q4 2016 report (Online):

https://www.akamai.com/uk/en/multimedia/docume nts/state-of-the-internet/q4-2016-state-of-theinternet-connectivity-report.pdf.

Received in final form on October 10, 2017 
Недашківський О.Л., Семенко А.І., Козлов О.С., Бокла Н.І.

Мережа Інтернет: моделі, технології, швидкість доступу, перспективи

Проблематика. Відкрита мультисервісна мережа електрозв'язку Інтернет стала найбільш використовуваним джерелом такої життєво-важливої інформації як: науково-технічної; інформаційної, розважальної і, особливо, комерційної. Сьогодні вона об'єднує 3,36 мільярдів користувачів і забезпечує високу економічну ефективність людської діяльності. При цьому існує багато різних технологій доступу до послуг мережі Інтернет, які конкурують між собою.

Мета досліджень. Створення моделі мережі Інтернет і моделі доступу до контенту, як основної цінності мережі 3 точки зору кінцевого користувача, для побудови ефективної мережевої інфраструктури.

Методика реалізації. А наліз всіх відомих публікацій, присвячених побудові і оцінці параметрів якості послуг мережі Інтернет. Аналіз технологій доступу до мережі і до контенту. Синтез моделі формування та розподілу трафіку між рівнями ієрархії мережі Інтернет.

Результати досліджень. Отримано укрупнені показники надання послуг мережі Інтернет. Запропоновано узагальнену схему побудови глобальної мережі Інтернет. На основі узагальненої схеми «з кінця в кінець» доступу користувача до послуг і ресурсів мережі отримана оцінка величини достатньої швидкості доступу. Визначено поняття рівня ієрархії і коефіцієнта тяжіння, для яких виведені математичні співвідношення.

Висновки. Основне завдання провайдерів будь-якого рівня максимально замкнути трафік якомога ближче до клієнта, тобто зменшити коефіцієнт тяжіння. Завдання теоретиків і інженерів - визначити теоретично оптимальне число рівнів (в розглянутій моделі їх було всього три) замикання або агрегації трафіку.

Ключові слова: Інтернет, мережа доступу, показник якості, показник доступності, швидкість доступу.

\section{Недашковский А.Л., Семенко А.И., Козлов А.С., Бокла Н.И.}

Сеть Интернет: модели, технологии, скорость доступа, перспективы

Проблематика. Открытая мультисервисная сеть электросвязи Интернет стала наиболее используемым источником такой жизненно-важной информации как: научно-технической; информационной, развлекательной и, особенно, коммерческой. Сегодня она объединяет 3,36 миллиардов пользователей и обеспечивает высокую экономическую эффективность человеческой деятельности. При этом существует множество различных технологий доступа к услугам сети Интернет, которые конкурируют между собой.

Цель исследований. Создание модели сети Интернет и модели доступа к контенту, как основной ценности сети с точки зрения конечного пользователя, для построения эффективной сетевой инфраструктуры.

Методика реализации. Анализ всех известных публикаций, посвященных построению и оценке параметров качества услуг сети Интернет. Анализ технологий доступа к сети и к контенту. Синтез модели формирования и распределения трафика между уровнями иерархии сети Интернет.

Результаты исследований. Получены укрупненные показатели предоставления услуг сети Интернет. Предложена укрупненная схема построения глобальной сети Интернет. На основе обобщенной схемы «из конца в конец» доступа пользователя к услугам и ресурсам сети получена оценка величины достаточной скорости доступа. Определены понятия уровня иерархии и коэффициента тяготения, для которых выведены математические соотношения.

Выводы. Основная задача провайдеров любого уровня максимально замкнуть трафик как можно ближе к клиенту, т.е. уменьшить коэффициент тяготения. Задача теоретиков и инженеров - определить теоретически оптимальное число уровней (в рассматриваемой модели их было всего три) замыкания или агрегации трафика.

Ключевые слова: Интернет, сеть доступа, показатель качества, показатель доступности, скорость доступа. 